\title{
A NosA-specific Bacteriophage Can Be Used to Select Denitrification-defective Mutants of Pseudomonas stutzeri
}

\author{
By MARTA A. CLARK, YAJARAYMA J. TANG AND \\ JOHN L. INGRAHAM* \\ Department of Microbiology, University of California, Davis, California 95616, USA
}

(Received 15 May 1989; accepted 23 June 1989)

\begin{abstract}
$\phi$ PS5, a double-stranded DNA bacteriophage of Pseudomonas stutzeri JM604 that adsorbs specifically to the outer-membrane protein NosA, was isolated from stagnant irrigation ditch water. Mutant strains that do not produce NosA are resistant to $\phi$ PS5 and cannot grow anaerobically with $\mathrm{N}_{2} \mathrm{O}$ as the sole electron acceptor. $\phi \mathrm{PS} 5$ did not adsorb to nos $A$ mutants and adsorption to the wild-type strain was reduced when cells were grown with a high concentration of copper, a condition that represses the synthesis of NosA. The isolation of spontaneous $\phi$ PS5resistant mutants yielded strains that were clearly defective in growth on $\mathrm{N}_{2} \mathrm{O}$ at about a $10 \%$ incidence. About half of these strains could respire $\mathrm{N}_{2} \mathrm{O}$ when supplied with a high concentration of exogenous copper.
\end{abstract}

\section{INTRODUCTION}

Biological denitrification is the reduction of nitrate or nitrite to gaseous products, either nitrous oxide $\left(\mathrm{N}_{2} \mathrm{O}\right)$ or dinitrogen $\left(\mathrm{N}_{2}\right)$. In Pseudomonas stutzeri JM300, the final step in the pathway, the reduction of $\mathrm{N}_{2} \mathrm{O}$ to $\mathrm{N}_{2}$, requires NosA, a $65000-M_{\mathrm{r}}$ copper-containing protein located in the outer membrane (Mokhele et al., 1987; Lee et al., 1989). Some nosA strains were isolated using frameshift mutagenesis (ICR-191; Polysciences Inc.) and counterselection for an inability to grow anaerobically with $\mathrm{N}_{2} \mathrm{O}$ as the only electron acceptor (Mokhele et al., 1987); i.e. these mutants selected as being denitrification-defective lacked the outer-membrane protein NosA. In order to explore further the relationship between defects in NosA and denitrification, we sought a method of selecting directly for mutations in nos $A$ using phage resistance. Outermembrane proteins act as phage receptors in Escherichia coli (Datta et al., 1977) and Salmonella typhimurium (Nurminen et al., 1976). Although detectable levels of NosA are present in the outer membrane of $P$. stutzeri only when cultures are grown anaerobically in an environment with a low concentration of copper, it seemed possible that NosA might be a receptor for some phage. Such a phage could be used to isolate phage-resistant, and thereby NosA-defective, mutants. Here we report the isolation of a NosA-specific phage and its use in selecting phage-resistant mutants defective in $\mathrm{N}_{2} \mathrm{O}$ respiration $\left(\mathrm{Nos}^{-}\right)$.

\section{METHODS}

Bacteria and media. The Pseudomonas strains used in this study are listed in Table 1. LT medium was modified Luria-Bertani broth (Carlson et al., 1983) supplemented with trace minerals solution lacking added copper $\left(1.0 \mathrm{ml}^{-1}\right)$ (Mokhele et al., 1987); by atomic absorption spectroscopy, this medium was found to contain 1.0 $\mu \mathrm{M}$-copper. LT-nitrate medium was LT containing $40 \mathrm{~mm}-\mathrm{NaNO}_{3}$. Plate and overlay media were solidified with $1.5 \%(\mathrm{w} / \mathrm{v})$ and $0.75 \%(\mathrm{w} / \mathrm{v})$ agar, respectively. The overlay medium was LT-nitrate supplemented with $\mathrm{CaCl}_{2}$ (10 mM) and $\mathrm{MgCl}_{2}$ (10 mM). LT with $\mathrm{CaCl}_{2}(10 \mathrm{mM})$ and $\mathrm{MgCl}_{2}$ (10 mM) (LTCM) was used to dilute phage suspensions. Phosphate-buffered saline ( $\mathrm{pH} 7 \cdot 2$ ) contained $1.27 \mathrm{~g} \mathrm{Na}_{2} \mathrm{HPO}_{4}, 0.41 \mathrm{~g} \mathrm{KH}_{2} \mathrm{PO}_{4}$ and $7.36 \mathrm{~g} \mathrm{NaCl} 1^{-1}$.

Growth of bacteria. Host bacteria were grown overnight in LT-nitrate. Unless indicated otherwise, all incubations were stationary at $30^{\circ} \mathrm{C}$ and all plate cultures were incubated anaerobically in an $\mathrm{H}_{2} / \mathrm{CO}_{2}$ atmosphere (Oxoid) for $24 \mathrm{~h}$. 


\section{Table 1. Bacterial strains and $\phi P S 5$ host range}

\begin{tabular}{|c|c|c|c|c|}
\hline Species & Strain & $\begin{array}{c}\text { Genotype } \\
\text { or phenotype }\end{array}$ & $\begin{array}{l}\text { Source or } \\
\text { reference }\end{array}$ & $\begin{array}{c}\text { Lysis } \\
\text { pattern* }\end{array}$ \\
\hline \multirow{18}{*}{$\begin{array}{l}\text { Pseudomonas } \\
\text { aeruginosa } \\
\text { Pseudomonas } \\
\text { alcaligenes } \\
\text { Pseudomonas } \\
\text { mendocina } \\
\text { Pseudomonas } \\
\text { pseudoalcaligenes } \\
\text { Pseudomonas } \\
\text { stutzeri }\end{array}$} & PAOl & & $\begin{array}{l}\text { T. C. Hollocher, } \\
\text { Branders Univ., }\end{array}$ & - \\
\hline & 12815 & & Waltham, MA & - \\
\hline & 25413 & Wild-type & ATCC & - \\
\hline & 17440 & & & - \\
\hline & JM299 & Rough & $\begin{array}{l}\text { B. A. Bryan \& } \\
\text { C. C. Delwiche, } \\
\text { Univ. of California, } \\
\text { Davis }\end{array}$ & - \\
\hline & JM300 & $\begin{array}{c}\text { Smooth } \\
\text { variant }\end{array}$ & Carlson et al. (1983) & + \\
\hline & JM604 & $n a l-7$ & & + \\
\hline & JM753 & nal-7 nos $A 14$ & & $\mathrm{~T}$ \\
\hline & JM757 & nal-7 nos $A 16$ & & $\mathrm{~T}$ \\
\hline & JM764 & nal-7 nosA19 & Mokhele et al. (1987) & - \\
\hline & JM766 & nal-7 nos $A 21$ & & - \\
\hline & JM769 & nal-7 nos $A 22$ & & - \\
\hline & JM790 & nal-7 nos $A 35$ & & - \\
\hline & 11607 & & & - \\
\hline & 17587 & & ATCC & - \\
\hline & 17682 & Wild-type & AlC & - \\
\hline & 17832 & & & - \\
\hline & ZoBell & & Döhler et al. (1987) & - \\
\hline
\end{tabular}

$*+$, Approximately 5000 clear plaques (semiconfluent lysis); T, 100-200 very turbid plaques; - , no plaques.

Isolation of phage. The method was based on those of Rao \& Labzoffsky (1969) and Primrose \& Day (1977). Samples $(400 \mathrm{ml})$ of stagnant irrigation ditch water collected in Yolo County, California were incubated at room temperature and inoculated each day with $20 \mathrm{ml}$ of an overnight culture of JM604. After $4 \mathrm{~d}$ samples were taken; cells and large particulate matter were removed by centrifugation $(6000 \mathrm{~g}, 15 \mathrm{~min})$. The supernatant was further clarified by filtration through an AP20 prefilter (Millipore) that had been washed with Tween $80(0.1 \%, \mathrm{w} / \mathrm{v})$ and water to prevent phage adsorption. The filtrate was then passed through a $47 \mathrm{~mm}$ HA membrane filter with $0.45 \mu \mathrm{m}$ pores (Millipore). The adsorbed phages were eluted from the filter by shaking (60 r.p.m.) for $1 \mathrm{~h} \mathrm{in} 4.0 \mathrm{ml}$ of $5 \times$ nutrient broth (Difco) in $0.05 \mathrm{M}$-bicarbonate buffer ( $\mathrm{pH}$ 9.0) (Hill et al., 1972). Chloroform was added to the phage-containing broth and plaques of different size and morphology were purified (Adams, 1959).

Titration of phage. Phage preparations were assayed by the agar overlay technique (Adams, 1959).

Preparation of high-titre lysates. Lysates were prepared by the method of Gliesche et al. (1988). The lysates were centrifuged $(5000 \mathrm{~g}, 15 \mathrm{~min})$ to remove whole cells and debris, and stored over chloroform at $4{ }^{\circ} \mathrm{C}$. Phage stocks routinely contained approximately $10^{10}$ p.f.u. $\mathrm{ml}^{-1}$.

Electron microscopy. $\phi$ PS5 was sedimented $(110000 \mathrm{~g}, 3 \mathrm{~h})$, washed, and resuspended in phosphate-buffered saline. One drop of the concentrated phage suspension (about $5 \times 10^{11}$ p.f.u. $\mathrm{ml}^{-1}$ ) was applied to a Formvarcoated copper grid; after $3 \mathrm{~min}$, excess sample was removed with a Kimwipe. Similarly, the phage particles were negatively stained with $2 \%(w / v)$ ammonium molybdate and washed with distilled water. Specimens were observed in a Zeiss EM109 electron microscope.

Host range. Different phage isolates were screened for infecting JM604 by spotting $1 \mu l$ of a preparation containing $10^{8}$ to $10^{10}$ p.f.u. $\mathrm{ml}^{-1}$ onto an overlay containing JM604 and examining for lysis following incubation. The host range of $\phi$ PS5 was determined by plating in an overlay the strain to be tested with the lowest $\phi$ PS5 dilution that gave semiconfluent lysis (approximately 5000 plaques per plate) on JM604.

Fluorescent staining of nucleic acid. The acridine orange fluorescent staining method of Bradley (1966) was used to determine the type and strandedness of the $\phi$ PS5 nucleic acid. The double-stranded DNA coliphage $\lambda$ gt1 1 (Promega) was employed as a control. The phage suspensions were incubated with $30 \mu \mathrm{g}$ DNAase I and RNAase A ml-1 at $37^{\circ} \mathrm{C}$ for $1 \mathrm{~h}$. Following two cycles of high- $(110000 \mathrm{~g}, 3 \mathrm{~h})$ and low-speed $(5000 \mathrm{~g}, 15 \mathrm{~min})$ centrifugation, the phage particles were resuspended in phosphate-buffered saline to give preparations containing approximately $10^{12}$ p.f.u. $\mathrm{ml}^{-1}$. Droplets were dried onto microscope slides for staining and other treatments. 
Molybdic acid was used after the $\mathrm{Na}_{2} \mathrm{HPO}_{4}$ soak. The results were confirmed by testing the sensitivities to DNAase and RNAase.

One-step growth experiment. The method of Eisenstark (1967) was used. $\phi$ PS5 was added to JM604 at an m.o.i. of $0 \cdot 1$. Phage antiserum was not used and withdrawn samples were treated with chloroform rather than being centrifuged.

Adsorption kinetics. An overnight culture was diluted 1:50 in LT-nitrate and incubated to early stationary phase. Cultures were harvested by centrifugation $(6000 \mathrm{~g}, 15 \mathrm{~min})$ and suspended in LTCM containing $200 \mu \mathrm{g}$ chloramphenicol $\mathrm{ml}^{-1}$ to give a cell density of $10^{9}$ c.f.u. $\mathrm{ml}^{-1}$. The chloramphenicol was included in the adsorption mixture to prevent NosA induction and phage synthesis; it did not interfere with adsorption. $\phi$ PS5 was added at an m.o.i. of 0.1 and the infected cultures were agitated $\left(60\right.$ r.p.m.) at $30^{\circ} \mathrm{C}$. Samples were removed at intervals, diluted 1:100 in cold LTCM containing chloroform, and assayed for unadsorbed phage.

Isolation of spontaneous $\phi P S 5$-resistant mutants. JM604 and $\phi$ PS5 were combined at an m.o.i. of 10-20 and incubated for $10 \mathrm{~min}$ to allow adsorption. The mixture was plated and incubated for $48 \mathrm{~h}$. The resulting colonies were purified aerobically on LT plates.

\section{RESULTS}

\section{Isolation and characterization of a NosA-specific phage}

Since $P$. stutzeri is found in soil and water (Palleroni et al., 1970), stagnant irrigation ditch water seemed to be a probable source of phages that infect it. Ten water samples were enriched for $P$. stutzeri phages by inoculation with a broth culture of JM604. Out of 53 phages collected, one isolate, $\phi$ PS5, formed plaques on JM604, but not on nos A derivatives of JM604 (JM753, JM757, JM764, JM766, JM769 and JM790) (Table 1). This suggested that NosA acted as a receptor for $\phi$ PS5 and that the property of phage resistance resulted from a defect in NosA. Two-dimensional gel electrophoresis had shown that these nosA strains did not produce detectable quantities of NosA (Mokhele et al., 1987).

Fluorescent staining with acridine orange indicated that $\phi$ PS5 contained double-stranded DNA, because the diagnostic green colour did not fade when treated with molybdic acid, and was eliminated by DNAase, but not RNAase, digestion.

The host range of $\phi$ PS5 was quite limited (Table 1). As expected, it lysed JM604, the strain used for enrichment. JM300, the parent of JM604, was also lysed. Yet the wild-type rough strain, JM299, from which JM300 was derived was immune to infection. Apparently, the large quantities of polysaccharide surrounding the JM299 cells prevented phage adsorption. $\phi$ PS5 did not infect five other $P$. stutzeri strains, notably strain ZoBell, the organism employed by W. G. Zumft and coworkers (Matsubara et al., 1982; Coyle et al., 1985; Riester et al., 1989). Recent experiments showed that NosA antiserum does not react with extracts from strain ZoBell (Lee et al., 1989). $\phi$ PS5 did not lyse any of the other four Pseudomonas species that belong to the same DNA homology group as P. stutzeri (Palleroni et al., 1973).

$\phi$ PS5 formed clear, small $(1 \mathrm{~mm})$ plaques. The particle morphology of $\phi$ PS5 resembled that of a Bradley type C phage (Bradley, 1967) (Fig. 1). $\phi$ PS5 had a hexagonal head approximately $40 \mathrm{~nm}$ in diameter and a short noncontractile tail.

One-step growth experiments with $\phi$ PS5 using early stationary phase cells of JM604 indicated a latent period of about $30 \mathrm{~min}$ followed by a burst of three phages per cell; then the phage titre continued to rise without reaching a plateau. The low burst size is not unusual for Pseudomonas phages (Sutton, 1966; Kelln \& Warren, 1971).

\section{Adsorption experiments}

To support the hypothesis that $\phi$ PS5 adsorbs to NosA, we sought to show that $\phi$ PS5 does not adsorb to cells lacking the NosA receptor and that NosA-repressing conditions reduce $\phi$ PS5 adsorption to wild-type cells (Fig. 2). Very few, if any $\phi$ PS5 particles adsorbed to the nos $A$ strain JM769, nor to another nos $A$ mutant JM753 (data not shown). Thus, the inability of $\phi$ PS5 to form normal plaques on nos $A$ mutants (Table 1) is a consequence of $\phi$ PS5 being unable to adsorb to these strains, probably because NosA is the phage receptor. If so, strains grown in the presence of elevated concentrations (i.e. greater than $10 \mu \mathrm{M}$ ) of exogenous copper, which represses the synthesis of NosA (Lee et al., 1989), might be expected to be poor phage-adsorbers. Indeed, the phage adsorption rate (Adams, 1959) was maximum for JM604 cells grown with low copper 


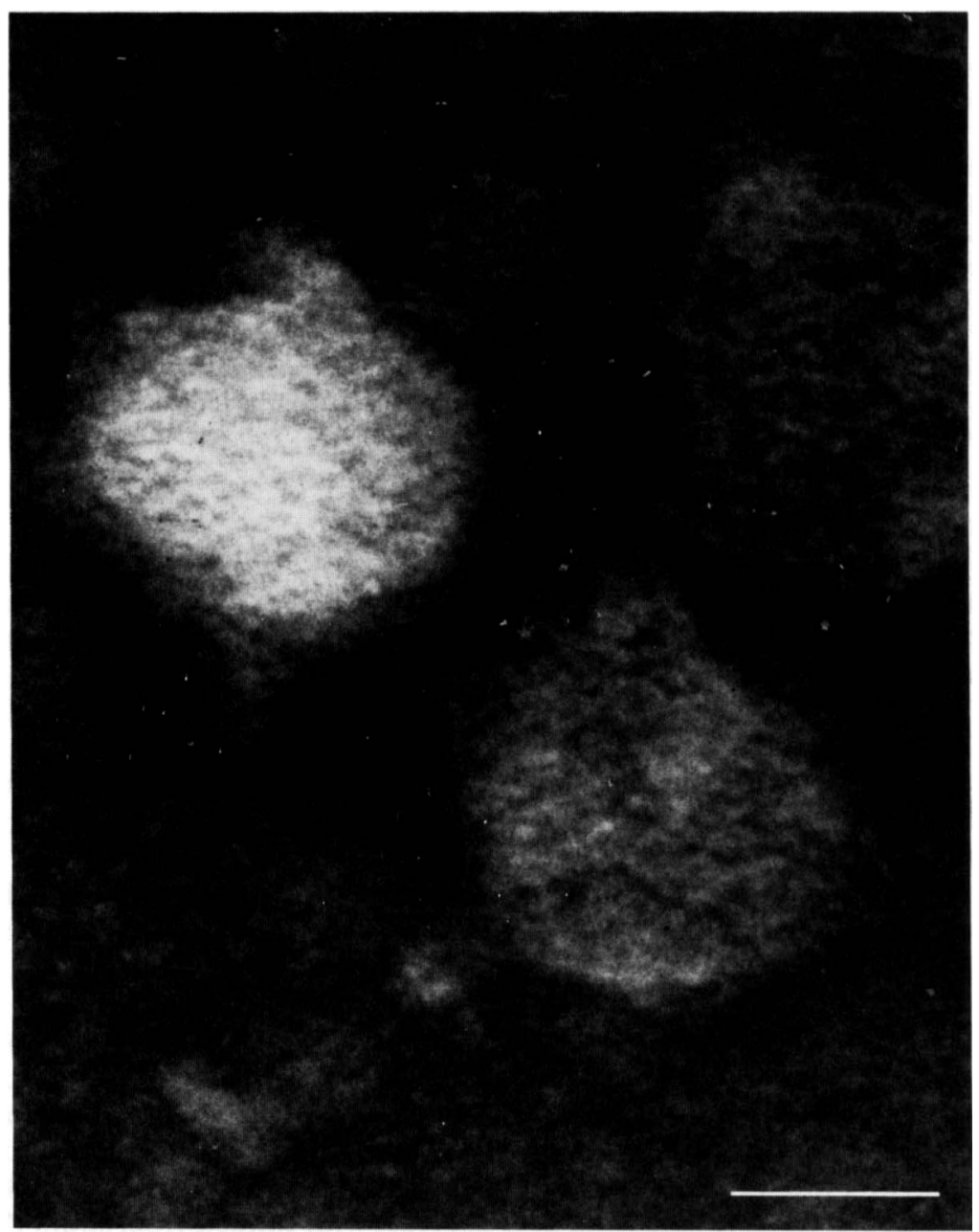

Fig. 1. Electron micrograph of $\phi \mathrm{PS} 5$ stained with ammonium molybdate. Bar, $10 \mathrm{~nm}$.

$(1.0 \mu \mathrm{M})$ (Fig. 2), and $35 \%$ lower (for the first $10 \mathrm{~min}$ of infection) for cells grown with a high copper concentration $(200 \mu \mathrm{M})$. This reduced level of adsorption is not sufficient to interfere with plaque formation; a high copper concentration $(400 \mu \mathrm{M})$ in solid media did not decrease the number or size of plaques formed. $\phi$ PS5 adsorption to aerobically grown cells could not be tested easily, because of the difficulty of maintaining fully aerobic conditions in full-grown cultures, the growth phase in which anaerobically grown cultures were tested, because they contain maximum levels of NosA.

\section{Isolation and characterization of $\phi P S 5$-resistant mutants defective in $\mathrm{N}_{2} \mathrm{O}$ respiration}

Chemical mutagens were not used because the frequency of spontaneous $\phi$ PS5 resistance was high $\left(10^{-6}\right)$. Following purification to remove contaminating $\phi$ PS5-sensitive (and presumably $\mathrm{Nos}^{+}$) cells, 500 putative $\phi$ PS5-resistant isolates were scored for anaerobic growth with $\mathrm{N}_{2} \mathrm{O}$ on LT plates containing either low $(1.4 \mu \mathrm{M})$ or high $(300 \mu \mathrm{M})$ copper. Exogenous copper is essential for $\mathrm{N}_{2} \mathrm{O}$ respiration (Matsubara et al., 1982) because $\mathrm{N}_{2} \mathrm{O}$ reductase contains copper (Coyle et al., 1985). Thus, the copper concentration of the LT-nitrate medium was enriched slightly (to $1.4 \mu \mathrm{M}$ ) to improve $\mathrm{N}_{2} \mathrm{O}$-dependent growth. Approximately $10 \%$ of the $\phi \mathrm{PS} 5$-resistant strains were clearly defective in growth with $\mathrm{N}_{2} \mathrm{O}\left(\mathrm{Nos}^{-}\right)$. We presume that the remaining $(90 \%) \phi$ PS5- 


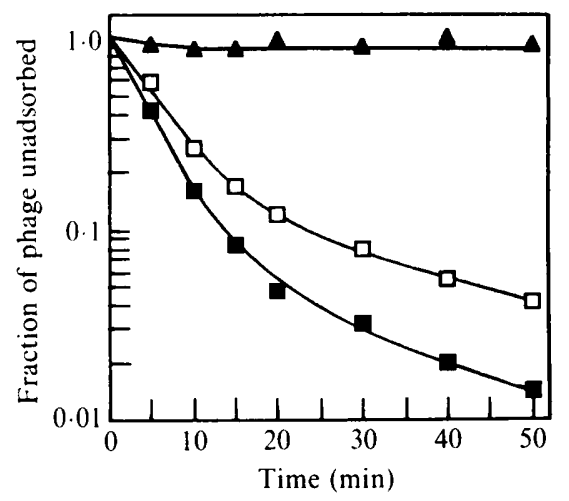

Fig. 2. Adsorption of $\phi$ PS5 to JM604 ( $(\mathbf{)})$ and JM769 ( $)$ grown with a low concentration of copper $(1.0 \mu \mathrm{M})$, and to JM604 ( $\square)$ grown with a high concentration of copper $(200 \mu \mathrm{M})$.

Table 2. Phenotypic characterization of $\varphi$ PS5-resistant mutants defective in $\mathrm{N}_{2} \mathrm{O}$ respiration

\begin{tabular}{|c|c|c|c|}
\hline \multirow[b]{2}{*}{$\begin{array}{l}\text { Strain or } \\
\text { mutant class }\end{array}$} & \multicolumn{2}{|c|}{ Growth with $\mathrm{N}_{2} \mathrm{O}^{*}$} & \multirow[b]{2}{*}{$\begin{array}{c}\text { No. } \\
\text { of isolates }\end{array}$} \\
\hline & $\begin{array}{c}\text { Low } \mathrm{CuSO}_{4} \\
(1.4 \mu \mathrm{M})\end{array}$ & $\underset{(300 \mu \mathrm{M})}{\mathrm{High} \mathrm{CuSO}_{4}}$ & \\
\hline JM604 (wild-type) & + & + & \\
\hline $\mathrm{JM} 753(\operatorname{nos} A)$ & - & - & \\
\hline I & - & - & 15 \\
\hline II & - & + & 6 \\
\hline III & $\mathbf{w}$ & $\mathbf{w}$ & 11 \\
\hline IV & w & + & 19 \\
\hline
\end{tabular}

resistant clones had defects in NosA that impaired receptor function but did not alter the NosA activity sufficiently to prevent growth on $\mathrm{N}_{2} \mathrm{O}$. The $\phi$ PS5-resistant, $\mathrm{Nos}^{-}$mutants fell into four phenotypic classes (Table 2). In a low copper medium (1.4 $\mu \mathrm{M}$ ), classes I and II did not grow with $\mathrm{N}_{2} \mathrm{O}$; classes III and IV grew weakly. When the copper concentration was increased to $300 \mu \mathrm{M}$, classes II and IV grew like the wild-type. High copper was not remedial for frameshift nos $A$ mutants (e.g. JM753).

\section{DISCUSSION}

Ten nos $A$ mutants were isolated previously using frameshift mutagenesis (Mokhele et al., 1987). These strains lacked Nos $A$ and produced an inactive, copper-free $\mathrm{N}_{2} \mathrm{O}$ reductase. These results suggested that NosA was necessary for copper to enter $\mathrm{N}_{2} \mathrm{O}$ reductase. Yet concentrations of exogenous copper up to toxic levels did not permit these nos $A$ strains to grow anaerobically with $\mathrm{N}_{2} \mathrm{O}$ as the sole electron acceptor. We concluded that NosA did not function exclusively to take copper into the cell; rather, it participated in the insertion of copper into $\mathrm{N}_{2} \mathrm{O}$ reductase. But, since frameshift mutations can exert polarity effects on downstream genes, it is possible that other proteins not expressed in frameshift mutants may participate in the pathway through which exogenous copper is inserted into $\mathrm{N}_{2} \mathrm{O}$ reductase. Some of these proteins might be required only with low concentrations of exogenous copper; others might be required at all concentrations. This suspicion was strengthened when we recently found that NosA is a channel-forming protein (Lee et al., 1989). NosA may function as a copper channel when the level of exogenous copper is low (i.e. less than $10 \mu \mathrm{M}$ ). When the copper concentration is high, 
copper may enter the cell by a NosA-independent route and may be inserted into $\mathrm{N}_{2} \mathrm{O}$ reductase by a different protein. Thus, it became important to be able to select directly for nos $A$ mutants and to determine their effect on $\mathrm{N}_{2} \mathrm{O}$ reductase activity at various concentrations of exogenous copper. We chose to select for NosA-defective strains by isolating strains that were resistant to a NosA-specific phage. Such a phage, $\phi$ PS5, was isolated from stagnant irrigation ditch water. Curiously, this phage can infect its host only when it is growing under the special conditions that allow NosA to be expressed - anaerobiosis and a low concentration of exogenous copper.

The host range of $\phi$ PS5 is limited to $P$. stutzeri JM300 and its derivatives, including JM604. The particle morphology was similar to that of the Pseudomonas phage gh-1 (Liss et al., 1981).

The properties of mutant strains that are resistant to $\phi$ PS5 seem to support the hypothesis that other proteins are needed to insert copper into $\mathrm{N}_{2} \mathrm{O}$ reductase. Out of 51 phage-resistant strains that were defective in $\mathrm{N}_{2} \mathrm{O}$ reduction (Table 2), about half (classes II and IV) regained their ability to reduce $\mathrm{N}_{2} \mathrm{O}$ when high concentrations of exogenous copper were made available to them. We are now investigating other proteins in the copper pathway.

We are grateful to Michael Dunlap for the electron microscopy work. We thank David Pratt for his advice and encouragement. We also thank Heung Lee for critical advice. This work was supported by grant no. DE-FG0385ER13356 from the US Department of Energy and grant no. 84-CRCR-1-1405 from the US Department of Agriculture.

\section{REFERENCES}

AdAms, M. H. (1959). Bacteriophages. New York, London \& Sydney: Interscience.

BRadley, D. E. (1966). The fluorescent staining of bacteriophage nucleic acids. Journal of General Microbiology 44, 383-391.

BradLEY, D. E. (1967). Ultrastructure of bacteriophages and bacteriocins. Bacteriological Reviews 31, 230-314.

Carlson, C. A., Pierson, L. S., Rosen, J. J. \& Ingraham, J. L. (1983). Pseudomonas stutzeri and related species undergo natural transformation. Journal of Bacteriology 153, 93-99.

Coyle, C. L., Zumft, W. G., Kroneck, P. M. H., KÖRNER, H. \& JAKOB, W. (1985). Nitrous oxide reductase from denitrifying Pseudomonas perfectomarina. Purification and properties of a novel multicopper enzyme. European Journal of Biochemistry 153, 459-467.

DATTA, D. B., ARDEN, B. \& HenNING, U. (1977). Major proteins of the Escherichia coli outer cell envelope membrane as bacteriophage receptors. Journal of Bacteriology 131, 821-829.

DöHLER, K., Huss, V. A. R. \& Zumft, W. G. (1987). Transfer of Pseudomonas perfectomarina Baumann, Bowditch, Baumann, and Beaman 1983, to Pseudomonas stutzeri (Lehmann and Neumann 1896) Sijderius 1946. International Journal of Systematic Bacteriology 37, 1-3.

EISENSTARK, A. (1967). Bacteriophage techniques. Methods in Virology 1, 449-524.

Gliesche, C. G., Holm, N. C., Beese, M., NeumanN, M., Völlker, H., Gebers, R. \& Hirsch, P. (1988). New bacteriophages active on strains of Hyphomicrobium. Journal of General Microbiology 134, 1339-1353.

Hill, W. F., JR, AKIN, E. W., Benton, W. H. \& MetCalf, T. G. (1972). Virus in water. II. Evaluation of membrane cartridge filters for recovering low multiplicities of poliovirus from water. Applied Microbiology 23, 880-888.
Kelln, R. A. \& WARREN, R. A. J. (1971). Isolation and properties of a bacteriophage lytic for a wide range of pseudomonads. Canadian Journal of Microbiology 17, 677-682.

Lee, H. S., Hancock, R. E. W. \& Ingraham, J. L. (1989). Properties of a Pseudomonas stutzeri outer membrane channel-forming protein (NosA) required for production of copper-containing $\mathrm{N}_{2} \mathrm{O}$ reductase. Journal of Bacteriology 171, 2096-2100.

Liss, A., ACKermanN, H.-W., MaYer, L. W. \& ZIERDT, C. H. (1981). Tailed phages of Pseudomonas and related bacteria. Intervirology 15, 71-81.

Matsubara, T., Frunzke, K. \& Zumft, W. G. (1982). Modulation by copper of the products of nitrite respiration in Pseudomonas perfectomarinus. Journal of Bacteriology 149, 816-823.

Mokhele, K., Tang, Y. J., Clark, M. A. \& INGRAHAM, J. L. (1987). A Pseudomonas stutzeri outer membrane protein inserts copper into $\mathrm{N}_{2} \mathrm{O}$ reductase. Journal of Bacteriology 169, 5721-5726.

Nurminen, M., LounatmaA, K., Sarvas, M., MÄKELÄ, P. H. \& NAKAE, T. (1976). Bacteriophageresistant mutants of Salmonella typhimurium deficient in two major outer membrane proteins. Journal of Bacteriology 127, 941-955.

Palleroni, N. J., Doudoroff, M., Stanier, R. Y., Solánes, R. E. \& Mandel, M. (1970). Taxonomy of the aerobic pseudomonads: the properties of the Pseudomonas stutzeri group. Journal of General Microbiology 60, 215-231.

Palleroni, N. J., Kunisawa, R., Contopoulou, R. \& Doudoroff, M. (1973). Nucleic acid homologies in the genus Pseudomonas. International Journal of Systematic Bacteriology 23, 333-339.

Primrose, S. B. \& DAY, M. (1977). Rapid concentration of bacteriophages from aquatic habitats. Journal of Applied Bacteriology 42, 417-421.

RaO, N. U. \& Labzoffsky, N. A. (1969). A simple method for the detection of low concentration of viruses in large volumes of water by the membrane 
filter technique. Canadian Journal of Microbiology 15, 399-403.

Riester, J., ZumfT, W. G. \& KRONECK, P. M. H. (1989). Nitrous oxide reductase from Pseudomonas stutzeri. Redox properties and spectroscopic characterization of different forms of the multicopper enzyme. European Journal of'Biochemistry 178, 751-762.

SuTton, M. D. (1966). Bacteriophages of Pseudomonas atrofaciens in cereal seeds. Phytopathology 56, 727-730. 